\title{
Gamete and embryo donation regulation in human assisted reproduction technologies: Disclosure or nondisclosure?
}

\author{
Rosa Verónica Esparza-Pérez \\ Universidad Nacional de Educación a Distancia, Madrid, Spain
}

\begin{abstract}
The use of donated gametes and embryos in assisted reproduction techniques (ART) makes it necessary to examine interests that involve relevant ethical and legal considerations, which include the autonomy and privacy rights of the intended parents, donors' right to privacy and the right of the minors to know their genetic origin. This article presents arguments to consider policies of more openness to obtain information from donors in order to protect the child's best interest in knowing his/her genetic origins. It concludes with the situation in Mexico, where ART has been carried out with donated gametes since several years ago; however, due to the absence of regulations to control these procedures, each establishment imposes its own criteria for the operation of its programs.
\end{abstract}

KEY WORDS: Genetic identity. Child's best interest. Gamete and embryo donation.

\section{Introduction}

Before the appearance of assisted reproductive technologies of (ART) there was only procreation by natural means, through intercourse; therefore, biological issues necessarily comprised genetic aspects, due to the impossibility to dissociate them. Now, with assisted human reproduction procedures, the biological contribution no longer necessarily includes the genetic part, and neither do genetic issues include biological aspects. Currently, the contribution can be exclusively genetic, which is the case of heterologous ART with genetic material from donors.

ARTs include in vitro management of human oocytes, sperm and embryos for reproduction purposes. This includes, but is not limited to, in vitro fertilization, embryo transfer, intracytoplasmic injection, embryo biopsy, preimplantation genetic testing, assisted hatching, gamete intrafallopian transfer, zygote intrafallopian transfer, gamete and embryo cryopreservation, semen, oocyte and embryo donation and gestational carrier cycles. Therefore, ARTs do not include artificial insemination using semen from the woman's partner or a donor. ${ }^{1}$

The development of ARTs and the willingness of people to donate their gametes and embryos for the treatment of others has made it possible for many people to be able to have offspring. In the United Kingdom alone, between 1992 and 2009, 31,000 children were conceived with donated gametes. ${ }^{2}$ In the United States, in the last 20 years, births from gamete donations increased from 30,000 to 60,000; however, these figures they are only estimates due to the limited registration system. ${ }^{3}$

As germ cell donation becomes more common, it becomes necessary to examine interests that involve relevant ethical and legal considerations, which include the rights to autonomy and privacy of the intended parents, donors' right to privacy and the right of minors to know their genetic origin. ${ }^{4}$ At this point, it is necessary taking into account that the expressions genetic origin and biological origin are not exactly equivalent: the former refers to the so-called genetic inheritance, or genetic heritage. The extraordinary
Date of reception: 23-02-2018

Date of acceptance: 28-08-2018

DOI: 10.24875/GMM.M19000225
Gac Med Mex. 2019;155:3-13

Contents available at PubMed www.gacetamedicademexico.com 
progress of technique has favored the access to the knowledge of this origin since, when there is undoubted material, the probability of arriving at the exact information is nowadays very high. The expression biological origin encompasses, in addition to genetic data, other comprehensive aspects of the life (bios) of a person, such as the emotional ties with other people (grandparents, siblings, etc.) that make up an individual's own history. ${ }^{4}$

One of the most debated issues at the time of legislation has been, and continues to be, the question of whether heterologous ART procedures should be carried out in secret and anonymously, or with greater openness in order to guarantee the right of children born through these donations to know their genetic origin, with no intention of questioning the already determined filiation. Although anonymity remains the most common practice in the world, there has been a political tendency towards a more open approach to obtaining donor information, with the intention of sharing it with the future parents and for potential disclosure to the future offspring. ${ }^{5}$

The reasons for this transition towards greater openness regarding donor information of are based, among others, on the right to know the genetic identity as part of the right to identity, essentially -though not exclusively- of minors. Cases related to the rights of children are complex because this branch of the law must be governed by principles of its own, which sometimes are different from those of the law in general, such as the principle that protects the best interests of the child. ${ }^{6}$ The best interests of the child, implies that their development and the full exercise of their rights should be regarded as guiding criteria for the development of standards and their application in all aspects related to the child's life. ${ }^{7}$ The right to identity from the perspective of the children's rights must be specifically addressed; therefore, this article addresses the right to genetic identity of children conceived with the help of donors, from the perspective of the children's rights.

The last part of this article describes the particular case of Mexico, where the proliferation of centers where assisted reproductive procedures are practiced and the elevated number of children who have been conceived with the help of these technologies reveal the existence of a global market. In spite of this, the federal legislator has thus far not adopted regulations that foresee the general aspects of access to and provision of services. Owing to the absence of clear regulations, the managers of both public and private clinics operate their gamete and embryo donation programs based on their own criteria, on academic standards or on guidelines issued based on expert consensus, which, regardless of professionalism and quality in medical care, leaves the users in a situation of vulnerability and legal insecurity.

\section{Identity, genetic data and genetic identity concepts}

\section{Identity}

The Royal Spanish Academy defines the concept of identity as "a set of traits that are inherent to an individual or a group and that characterize them against others. Awareness a person has of being him/herself and different from others". Some authors have defined it as the "set of attributes and characteristics that allow the person to be individualized in society [...] it is everything that makes each one to be his/her own self and not anybody else". ${ }^{8}$ The concept of identity can include both the right to know the genetic origin and other elements necessary for the filial relationship to be determined. For this article, the aspect we are interested in will be the right to genetic identity.

\section{Genetic data}

Our genetic material accompanies us from the first stages of life and until death. By applying a series of methodological techniques, it is possible to extract certain specific information, which is currently called "human genetic data". 9 Genetic data applicative potential has become a relevant factor for various activities related to health and healthcare. Genetic data may indicate individual genetic predispositions -not necessarily of a pathological nature- of future and uncertain importance, such as providing useful information for the development of scientific research aimed at detecting and curing diseases and providing relevant information that may go beyond the individual scope to affect the offspring; they can provide data for the future, even if the relevance of that information is not known at the time of extracting biological samples. ${ }^{10}$

The UNESCO 2003 International Declaration of Human Genetic Data understands by genetic data the following: "any information about people hereditary characteristics, obtained by nucleic acid analysis or other scientific analysis". On the other hand, Council 
of Europe Recommendation (97) 5 defines them as "all data, regardless of their type, that refer to the hereditary characteristics of a person or to the inheritance pattern of these characteristics in a group of the same family".

Therefore, DNA techniques reveal the unique nature of each person, and the data that can be obtained through its analysis reveal sensitive areas of a person's private life and own physical reality. Human genetic data have special features that distinguish them from others, since they impact not only on the person these data belong to, but they are also important for the family as a whole, especially for its offspring; therefore, adopting measures to protect rights that may be compromised with these techniques, including the right to genetic identity, is deemed necessary.

\section{Genetic identity}

Since the identification of DNA, genetics constitutes a type of privacy. The discoveries around this acid have allowed reaching an accurate knowledge of our genetic identity. The disclosure of genetic privacy can affect not only the subject whose private life is concerned, but it can also interfere with his/her offspring and other members of his/her family group with whom he/she shares certain genetic traits. ${ }^{9}$

The International Declaration on Human Genetic Data and Human Rights recommends the States to strive to protect the privacy of individuals and the confidentiality of human genetic data associated with a person, a family or, where appropriate, an identifiable group. This instrument proposes some rules on how these data should be dealt with, one of which is that genetic data of an identifiable person should not be disclosed or be accessible to third parties, except with the consent of the person in question.

Like all rights, the rights to privacy and genetic data confidentiality admit limitations and can be restricted in consideration of other rights and legal interests, ${ }^{10}$ as it would be the case of children born by means of assisted reproduction procedures with donated genetic material, in whom knowing this information helps them to learn about their genetic origin. The best interests of the minor are considered to predominate. ${ }^{9}$

Except in cases where the best interests predominate, the genetic data of an identifiable person shall not be disclosed to third parties, except in cases provided by domestic law or when the consent of the person that information belongs to is obtained.

\section{The right to know the genetic origin}

The advance in genomic medicine and its implications in health makes the knowledge of genetic origin increasingly important as a means to know the predisposition to develop potentially preventable diseases (e.g., by modifying the lifestyle) ${ }^{9}$ and to prevent the risk of marriage or procreation with a blood relative. ${ }^{6}$ The lifting of anonymity in heterologous ART is based upon the idea that protecting the best interests of children to know their origins should guide the legal approach. In that sense, Irène Théry clarifies: ${ }^{11}$

We don't mean to say that the psychological interests of an individual-child are granted more importance than to those of other individual-adults, but rather that donation in assisted reproduction is legally defined as a social act that acquires its particular sense and value due to the fact that all parties contractually involved in the begetting must concur to organize this to the benefit of that individual who, once born, will be considered as a legal entity, subject of rights.

In legal terms, the best interests of the child are negatively defined here as the right not to be a priori and definitively deprived of information on the identity of the people that have allowed him/her to be born, and, in a positive form, this right can be formulated as having the possibility to decide if he/she wants to know or ignore the donor's identity. ${ }^{11}$ But the right not to know, as a manifestation of freedom versus knowing, implies that there is already knowledge about the fact that generates this right, that it is already known. ${ }^{12}$

At the international level, the principle of the child's best interests ${ }^{6,13}$ is recognized in article 3.1. of the Convention on the Rights of the Child, which establishes:

In all measures concerning children, taken by public or private social welfare institutions, courts, administrative authorities or legislative bodies, an essential consideration to be addressed shall be the best interests of the child.

Although the Convention on the Rights of the Child does not specifically promote the child's right to know about his or her origin, in article 7 , it establishes that the child will have the right, to the extent possible, to know his/her parents, and that it is the responsibility of the States parties to ensure the application of these rights, in accordance with their national legislation and the obligations they have contracted in virtue of the relevant international instruments in this ambit. On the other hand, article 8 establishes that States parties undertake to respect the right of the child to preserve his or her identity, including his/her nationality, name 
and family ties in accordance with the law, without unlawful interference, and that when a child is illegally deprived of some or all of his/her identity elements, the States parties shall provide appropriate assistance and protection looking to rapidly reestablish his/her identity.

The United Nations Committee on the Rights of the Child, in charge of overseeing the implementation of the Convention on the Rights of the Child, has declared the desirability of allowing access to genetic origins; for example, in 2002 it issued a statement regarding the British legislation and pointed out: ${ }^{14}$

The Committee expresses concern that children born out of wedlock, adopted children or children born through medically assisted fertilization do not have the right to know the identity of their biological parents.

It recommended the State to adopt measures in order for all children, regardless of the circumstances of their birth, to be able to obtain, to the extent possible, information on the identity of their parents. ${ }^{14}$

Within the framework of the inter-American system for the protection of human rights, the recognition of the right to identity is closely linked to forced disappearance of persons. There are many cases that have been solved by the Inter-American Court of Human Rights where, although it is clarified that it is not a right expressly provided in the Inter-American Convention, its recognition derives from a systematic interpretation of articles 18 (right to a name) and 17 (right to protection of the family). ${ }^{15,16}$ Although the Inter-American Court of Human Rights has so far not had the opportunity to rule on cases where the right to identity of a person conceived through donated gametes or embryos is invoked, there is protection of the right to identity within the framework of the American Convention.

In the European realm, through several precedents (with "Gaskin vs. United Kingdom", of July 7, 1989, "Mikulic vs. Croatia", of February 7, 2002 and "Ebru et Tayfun Engin Çolak vs. Turkey ", of May 30, 2006 standing out), the European Court of Human Rights has concluded that respect for private life requires that people are able to establish details about their own identity as human beings and that, in principle, cannot be obstructed by the authorities to obtain that basic information without justified cause. It has also recognized the interest, protected by the European Convention on Human Rights, in obtaining the necessary information for the discovery of the truth about important aspects of their identity, for example, the identity of their parents.

\section{Positions in comparative law}

The regulation and practice of reproductive techniques with gamete donation is addressed with particularities in different countries. ${ }^{17}$ This review of some regulations in comparative law is not intended to be exhaustive, and its purpose is not entering in the complexity of different regulations, but only documenting the global trends on anonymity lifting in donations.

\section{Legislations that recognize the right of the child to know the donor's identity}

In 1984, Sweden amended its law to grant children born from sperm donation the right to know the identity of their donor once they are sufficiently mature. The Austrian law establishes the right of the child from 14 years of age on to have knowledge on the donor identity. In Finland, the law allows those conceived by donated gametes or embryos, from 18 years of age on, to know the identity of the donor. In the Netherlands, after 15 years of debates, donations stopped being anonymous since June $2004 .{ }^{11}$ In Norway, anyone born as a result of assisted reproduction using donated sperm has the right to information about the identity of the sperm donor, at the age of 18 years. ${ }^{18}$ Since 2004, New Zealand suppressed gamete donor anonymity and created a registry for voluntary establishment of contacts between donors, recipients and children born by assisted reproduction in order to respond, to the extent possible, to the demands for information regarding cases of donations prior to the law. ${ }^{11}$ In turn, in the year 2000, Holland approved a law stating that only non-anonymous donations are allowed and that clinics have the obligation to recruit non-anonymous donors. Finally, in the United Kingdom, ${ }^{19,20}$ after a public consultation and a subsequent reform in 2004, the Human Fertilization and Embryology Act allows those conceived as of April 1, 2005 through donated semen, eggs or embryos to request identification information on donors, once they turn 18.

In Latin American countries, where the general rule is still donor anonymity, Uruguay and Argentina have legislated in the opposite direction. However, none of them recognizes the right of the conceived individual to know his/her genetic origins, but only the possibility of requesting access to that information through legal channels. 


\section{Legislations that contemplate a double-track policy}

Some legislations allow the donor to benefit from anonymous or identifiable donation modalities, and users of the techniques, to use gametes from one or another type of donor, or else, they make access to donors' identity conditional to their written consent. This policy is known as double track ${ }^{21}$, and those who advocate for it argue that it has the advantages of self-regulation, well-being of the family as a whole and a recognition of moral plurality.

Against this model, it could be argued that it subordinates the right to know the origins to the exercise the donor makes or makes not of his right to privacy and secrecy, with greater weight given to this than to the right of people to know their genetic origins. ${ }^{8,21}$ This system is the one adopted by several territories of the United States, where most States have not regulated this issue, and the decision on donation anonymous nature or not depends on each medical center and user preferences.

\section{Legislations that protect donor anonymity}

The Spanish legislation maintains donor anonymity despite changes in the European setting*; the law only allows non-identifying donor data to be known. Thus, according to the precept, the general rule is that donor information that can be obtained by individuals conceived with donated gametes, either by themselves or by their legal representatives, is restricted to very basic data that do not include donors' identity.

In France, anonymity is the general rule. The Ministry of Health proposed its partial suppression in

* The Spanish Constitutional Court, in its 116/1999 ruling of June 17 , ended up declaring the anonymity rule adopted by Law 35/1998 to be constitutional. The right to privacy of the donor is not an absolute right, but gives in versus the right to life and physical integrity of the born individual and versus the right to obtain judicial protection. The donor's interest in defending his/her anonymity is prevalent in case the born individual alleges a simple interest in knowing his/her biological origin, since, otherwise, there would be no candidates willing to donate reproductive cells, which would result in a lack of protection of the right to health of sterile couples. The born individual will always be able to inquire about non-identifying donor data, without the concealment of the biological parent's identity being sufficient reason to claim that due protection of the children is being violated according to the Spanish Constitution.
2010 and the proposal was rejected, but an official report concluded that the Civil Registry should allow the child to know, once legal age is reached, the way he/she was conceived so that, if that's his/her wish, he/she requests to know the donor (s). However, the report subordinates that possibility to the donor's consent, since it maintains that anonymity is compatible with the right to private and family life..$^{15}$

On the other hand, in Italy, legislation on assisted reproduction initially prohibited heterologous fertilization, an aspect that was finally declared unconstitutional by the Italian Constitutional Court, in ruling 162 of April 9, 2014 (https://www.cortecostituzionale.it/actionSchedaPronuncia.do?anno=2014\&numero $=162$ ). In 2011, while the prohibition on heterologous fertilization was still in force, ${ }^{22}$ an official report recommended, in rather vague and imprecise terms, to recognize the right of the child, once legal age is reached, to access information about his/her own origins. ${ }^{15}$

\section{Arguments or justifications for not disclosing information}

The arguments that have been put forward to favor non-disclosing donor information models seek to preserve the connection of legal parents with their children despite the fact that there is no genetic link with one or both parents, as well as to facilitate that the children develop with greater stability. Another factor is not to disclose that the man or woman, or both if they are a couple, suffer from some reproductive dysfunction, a situation that in some societies can still be a stigma, ${ }^{23-25}$ and seeks to preserve donors' right to privacy.

With regard to the arguments for the benefit of intended parents, some studies refer that the reasons why parents decide not to inform their children about the way they were conceived answer to the need to avoid that they feel different from other family members and fear of the donor irruption in the family life..$^{15}$

Regarding the minor's interests, some studies indicate that a genetic relationship is not essential for good social upbringing or for a satisfactory emotional development of children, and that giving excessive importance to genetics is not the best way to guarantee the well-being of families that do not rely on it. ${ }^{26}$ In any case, the right of people born using gametes or embryos from donors to inquire about their true genetic origin, if they wish or require doing it, should be recognized. 
As regards donors' interests, it is usually argued that it is necessary to preserve anonymity in order to safeguard their right to privacy and confidentiality, as well as to avoid possible paternity claims. Previously, it was pointed out that the protection of donors' genetic data can be limited by the concurrence of the rights of third parties; this would be the case of the children's right to know their true origin and build their own genetic identity. On the other hand, disclosing donor information to children does not entail a recognition of filial obligations deriving from this genetic bond. An adequate legal framework should dissociate donors from any parental responsibility and from the obligations attributed to them by the law.

Frequently, it is argued that lifting anonymity would cause a decrease in the number of donations and would lead to greater difficulties for carrying out these procedures in the absence of means to accomplish them..$^{10,15,19,27 * *}$ Even if the referred argument had empirical support, its fit in the context of human rights is questionable, given that it is a utilitarian argument. In Scandinavian countries, where donor anonymity is no longer preserved, after a drop in donations, the number of donors has stabilized. ${ }^{27}$

\section{Arguments for disclosing information}

It is essential to start by recognizing that anyone who donates his/her genetic material does it in full exercise of his/her freedom, i.e., he/she voluntarily places him/herself in that situation; hence, it does not seem unreasonable to demand that he/she assumes the consequences of his/her actions. ${ }^{10}$ Conversely, a child conceived with donated gametes or embryos has been foreign to the act by means of which procreation was gained access to. ${ }^{18}$

Currently, one sector of fertility professionals is in favor of revealing donor identity in order to build family relationships based on honesty ${ }^{28}$, and consider that the fact that one person has relevant undisclosed information about another is detrimental to any relationship between two people, especially given the consequences that accidentally discovering this

** In the United Kingdom one year after the reform that suppressed donor's anonymity came into force, the forecasts that predicted a drop in the number of donations were found not to be fulfilled. In Sweden, a study conducted 15 years after the 1984 law entered into force shows that the number of donors has not decreased, and the North American centers that offer gametes from donors who agree to be identified have no problem recruiting them. information may have. In this regard, Mary Warnock claims that "concealing this information would be an obvious case of negligence towards the child's well-being". ${ }^{27}$

Another reason why it would be prudent to abolish anonymity is the advance regarding the knowledge of parental genome, since this is an important component in the guarantee of the right to health of conceived individuals; preimplantation genetic diagnoses can determine the treatment or decisive prevention of diseases, in addition to constituting relevant information at the moment the individual born of gamete donation him/herself decides to have children. ${ }^{15,26}$

Although it can be claimed that the minor has the right to know the truth about his/her genetic origin, it cannot be established that knowing it constitutes an obligation. However, the right not to know, as an expression of freedom versus knowing, implies that there is already knowledge about the fact that generates this right. Finally, it is argued that depriving a person of the knowledge about his/her origin implies denying him/her one of the fundamental elements that constitute his/her identity, based on which he/she differentiates from others and can be individualized in relation to those he/she originates from. ${ }^{6,10,19,28-30}$

\section{Situation prevailing in Mexico}

In Mexico, the proliferation of centers where assisted reproduction procedures are practiced, and the elevated number of children who have been conceived with their assistance, reveal the existence of a global market. Notwithstanding, up to this moment there is no relevant regulation on the subject that lays down the law on general aspects of access to and provision of assisted human reproduction services. Due to the absence of clear rules, those responsible for both public and private clinics operate their gamete and embryo donation programs based on their own criteria, academic standards or guidelines issued by consensus of experts in the field of infertility, which, regardless of professionalism and quality in medical and scientific care, leaves the users in a situation of vulnerability and legal uncertainty.

\section{Regulatory situation at the federal level}

The issuance of regulations applicable to health services, specifically with regard to assisted human reproduction procedures, is federal competence and, based on Article 73 of the Constitution, establishing 
the bases for their regulation corresponds to the General Statute Health. Article 3 of said law establishes that sanitary control of the destination of organs, tissues and cells is a matter of public health.

Regulation on the operation of public and private establishments where assisted human reproduction procedures are practiced, as well as of centers that operate as gamete banks, is the responsibility of the Federal Commission for the Protection against Sanitary Risk (Cofepris - Comisión Federal para la Protección contra Riesgos Sanitarios). However, its functions do not include maintaining a record on donors, nor does it require clinics to generate it.

A note on the subject of assisted human reproduction is currently under review in the House of Representatives. The ruling is advancing towards a proposal for the creation of a National Registry of Assisted Reproduction dependent on the federal Ministry of Health, which would work to collect statistical information on this practice in Mexico. ${ }^{31}$ In the same legislative period, another ruling of the House of Representatives Health Commission was presented, which prohibits the use of semen from anybody other than the partner, but not the use of eggs. ${ }^{32}$ In December 2017, another initiative was presented with the purpose to regulate $A R T,{ }^{33}$ which proposes for donation to be anonymous and confidentiality of donor identity data to be guaranteed, and that the right to obtain general information from gamete and embryo donors should only exist in extraordinary circumstances that entail a real threat to the life or health of the child, or when appropriate in accordance with criminal procedural laws, the donors' identity can be revealed to the interested party (article 7.5). ${ }^{33}$

Article 36 of the initiative rightly proposes the creation of a National Registry of Donors, whose function would be to register, based on data provided by health facilities, the record of gamete and embryo donors, with specific guarantee of confidentiality of their data, as well as a record of the children born from each one of the donors, identity of the couples or recipient women and the original location of all stakeholders at the time of donation and the use thereof. All three regulatory proposals must be discussed and analyzed, since they contain provisions that, if approved, might infringe human rights. ${ }^{34}$

\section{Situation in clinics and facilities that perform $A R T$ with donated gametes or embryos}

In the public field, the National Medical Center "20 de Noviembre" (which belongs to the Institute of
Security and Social Services for State Workers), the Maternal-Perinatal Hospital "Mónica Pretelini" (which belongs to the State of Mexico Health Institute) and the National Institute of Perinatology have a human reproduction biology program and apply highly complex reproductive techniques; however, due to the lack of an adequate legal framework, they are unable to perform ART with gametes and embryos from donors. ${ }^{35}$ The National Institute of Perinatology is the only institution that performs procedures with semen from donors -not with donated eggs and embryos-, but gametes are provided by external banks. ${ }^{35}$

In the private sector, given that there is no health authority responsible for requiring and publishing data generated by health establishments authorized to practice ART, it is difficult to obtain data and information on the practice and operation of donor programs. The information available on the Internet shows that donation is carried out based on confidential contracts between donors and authorized centers. ${ }^{36-47}$ The information of donors, recipients and children that might result from these procedures remains under the strictest anonymity. Donors can only be contacted by the responsible center in case the child's health requires it; for this, the center commits itself to indefinitely preserve donors' information. ${ }^{48}$ Centers that make any reference to this contact possibility, clarify that it will be between the clinic and the donor, but not with the legal parents or the child who requires the information. Some websites, the most comprehensive ones, point out that they constantly renew their base of semen donors and limit the number of pregnancies achieved with each sample to avoid the risk of inbreeding between children of different patients with a common donor. This suggests that, although there are no standards to regulate gamete and embryo donation in Mexico, the practice is governed by confidentiality and anonymity rules.

\section{The right of minors to know their genetic origin in national regulations}

The principle of the best interests of the child is based on the eighth paragraph of article 4 of the Political Constitution of the Mexican United States, and on article 3 , paragraph 1 , of the Convention on the Rights of the Child (ratified by Mexico on September 21, 1990 and published in the Official Gazette of the Federation of January 25, 1991), where it is stated that in any decision, action or measure involving children, the State has the unavoidable obligation to serve their best interests. 
Even when the constitutional precept wherein the rights of children are comprised does not refer to the minors' right to identity, its regulatory law, the Law for the Protection of the Rights of Children and Adolescents, establishes as integral parts of the right to identity, among others, the right to know their filiation and their origin, which in article 22, indicates:49

The right to identity is composed of: A. Having a name and the surnames of the parents since birth and being registered in the Civil Registry; B. Having a nationality, in accordance with the provisions of the Constitution; C. Knowing one's filiation and origin, except in cases forbidden by the laws; D. Belonging to a cultural group and sharing with its members customs, religion, idiom or language, without this being likely to be understood as a reason to oppose any of their rights. In order for children and adolescents to be able to fully exercise the right to their identity, the regulations of each State will be able provide whatever is it necessary for the mother and father to register them, without any distinction by virtue of the circumstances of their birth.

In turn, the Supreme Court of Justice of the Nation (SCJN - Suprema Corte de Justicia de la Nación) has ruled on the right to identity of children, by stating that this is made up of the right to have a name and the parental surnames since they are born, to have a nationality, to know their filiation and origin and to have certainty about who their progenitor is, which constitutes a principle of public order..$^{50}$ It has also been ruled that the right to identity is a right of the children and not a faculty of the parents, and although the tendency is for the legal filiation to be consistent with the biological filiation, this is not always possible, either due the very reality of the presumed fact or because the regulation makes other interests that are considered legally more relevant prevail, such as adoptive filiation and gamete donation-assisted procreation might be. ${ }^{51}$ Recently, it was argued that the right to identity in terms of knowledge of the biological nexuses of a person is related to an adequate development of personality, to the right to mental health, as well as to the right to know the relevant medical information derived from one's own genetic characteristics. The filiation relationship is not a necessary consequence of the establishment of the biological truth, and thus a person can be allowed to inquire about his/her biological origins without this necessarily entailing a filiation shift. ${ }^{52}$

\section{At the local level}

It has been local legislations that in civil or family codes have included some regulations on assisted reproduction procedures, particularly with regard to the civil status of people who are born as a result of these scientific advances. With opposing positions, the states of Sonora and Mexico have already ruled on paternity investigation in assisted human reproduction procedures.

The Family Code for the State of Sonora contemplates that the child may request, upon reaching adulthood, reports on the biological father in the same cases as in full adoption, without claiming any filiation rights. Article 207 indicates: ${ }^{53}$

\begin{abstract}
When pregnancy is attained by means of assisted reproduction techniques with genetic material from people other than one or both members of the couple, those who voluntarily use gametes from third parties will be regarded as the biological parents of the child born by these methods, as long as they have expressly granted their authorization. The child will be able request, upon reaching legal age, information on the biological father in the same cases as in full adoption, without claiming any filiation rights.
\end{abstract}

It does not clarify what kind of information can be obtained from donors or even if it is viable to know their identity; however, the numbered paragraph refers to the section that regulates full adoption. In this regard, the family code of that State stipulates the prohibition to inform on the background records of the adoptee, unless he/she him/herself requests it when he/she reaches legal age, after obtaining judicial authorization, in order to fully know his/her identity or to protect his/her health through the knowledge of possible hereditary diseases or at the request of the Public Prosecutor, in cases of criminal investigation (article 300). ${ }^{53}$

To this moment, the judicial power of that State has not resolved matters where legal action is related to the minor's right to know the donor identity, in the terms contemplated by the Family Code. ${ }^{54}$ The absence of trials in that State is probably due to the fact that there are few clinics, at least with registration before Cofepris, in addition to their relatively recent opening; however, the authorities might eventually know about disputes on this issue. While progress is made in the sense of opening the possibility that the child, upon reaching legal age, may request information about the donors who provided his/her genetic material, the absence of relevant regulations that force the managers of banks or clinics to preserve information, as well as the lack of donor records, can cause potential stakeholders to be faced with the situation that the clinic does not have the donor's information or that it does not operate anymore, in which case it would be physically impossible to exercise such right.

On the other hand, the State of Mexico Civil Code prohibits, in cases where artificial insemination is carried out with sperm -it does not foresee the possibility 
of oocytes or embryos- originating from banks or institutions legally authorized to disclose the donor's name and neither will a paternity investigation take place (article 4.115). ${ }^{55}$

This prohibition is considered to have legal consequences: what would happen if this information was necessary for the purpose to safeguard the health of the person born with the help of donated genetic material or to guarantee the right to know his/her genetic identity?

Currently, the official Mexican standard on the clinical record forces medical care institutions or providers to preserve patient information and data for a minimum period of five years. ${ }^{56}$ It provides that clinical records are the property of the medical care institution or provider that generates them, when it does not depend on an institution. Public sector institutions, in addition to the provisions of this rule, must observe the provisions on the subject that are in force. Notwithstanding the foregoing, the patient, as contributor of the information and beneficiary of the medical care, has ownership rights over the information for the protection of his/her health, as well as for the protection of the confidentiality of his/her data, in the terms of this regulation and other legal provisions that may be applicable. Due to the foregoing, since these are documents prepared in the interest and to the benefit of the patient, they must be preserved for a minimum period of five years, counted from the date of the last medical act. ${ }^{56}$

Evidently, the term contemplated by the official Mexican standard to preserve the medical record would be insufficient in the event of a request from the child to obtain information about his/her genetic parents. Additionally, there is a federal law that protects personal data held by private individuals, ${ }^{57}$ for the purpose to guarantee the privacy of people. The regulations stipulate that sensitive data will be those that affect the most intimate sphere of their owner, since they reveal aspects such as racial or ethnic origin, present and future health status, genetic information, religious beliefs, among others; this would be the case of the information provided by donors to those responsible for the clinics. In its article 3.6, it states the following: ${ }^{57}$

For the purposes of this Law, the following shall be understood as Sensitive personal data: Those personal data that affect the most intimate sphere of their owner, or whose improper use may give rise to discrimination or entail a serious risk for him/her. In particular, those data that can reveal aspects such as racial or ethnic origin, current and future health status, genetic information, religious, philosophical and moral beliefs, union affiliation, political opinions and sexual preferences are regarded as sensitive.

Although this law establishes that the envisaged principles of law will have the protection of the rights of third parties (article 4) as a limit in terms of their observance and exercise, ${ }^{57}$ it would be advisable for the right of a minor to obtain information about the donor in order to protect his/her right to know his/her genetic identity to be considered as an exception when the law that regulates assisted human reproduction is approved in Mexico.

Definitively, in the face of a collision between rights, seeking to harmonize them would be desirable; however, in an issue such as the one in question, in order for not to leave the child's right to identity unprotected, looking for a legal way to evaluate and weigh these rights becomes inevitable, and we have to establish which one is superior or more valuable, or whether restricting any fundamental right for a specific purpose is constitutional and, in that sense, solve the conflict. 58

\section{Final considerations}

From the above, it is concluded that the right to identity in terms of knowledge of the genetic origin of a person is related to the proper development of personality, to the right to health, as well as to the right to know the relevant medical information derived from an individual's own genetic characteristics. However, it should remain clear that the filiation relationship is not a necessary consequence of the establishment of genetic origin; therefore, although a person should be allowed to investigate his or her genetic origins, this does not entail a filiation shift, as well as parental obligations and responsibilities for the people from whom the donated genetic material originates.

We share the opinion of specialists who consider it convenient that heterologous assisted reproduction procedures do not operate under the principles of secrecy, anonymity and confidentiality, with this being supported by the idea that it is the protection of the children's best interests in knowing their genetic origins, what should direct the legal approach.

Up to this moment, Mexico does not have a normative framework that regulates the general aspects of access to and provision of assisted human reproduction services. It has been some local legislations that, in civil or family codes, have included aspects about these procedures, in particular about the civil status 
of people conceived using these scientific advances. That is the case of Sonora, which although it empowers the child, upon reaching legal age, to request information about the donors that provided his/her genetic material, the absence of relevant regulations that force those responsible of banks or clinics to preserve the information and the lack of donor registries can make for those interested to be faced with the fact that the clinic does not have the required information or that it does not operate anymore, in which case it would be impossible to exercise such right.

Therefore, it is necessary to discuss, in a multidisciplinary manner, the issuance of a normative framework that regulates the medical-scientific and ethical performance of health personnel and establishments that carry out assisted human reproduction procedures. It would be advisable to consider the creation of a national registry of donors, dependent on the federal Ministry of Health, whose function would be the registration of gamete and embryo donors, based on the information provided by those responsible for establishments authorized to practice assisted reproduction procedures.

This single registry would enable the registration of the children born from each donor, in order to avoid the risk of inbreeding between children of different patients with a common donor, the registration of the identity of the couples or recipient women and the original location of each one at the time of the donation and the use thereof. It would also warrant access to information to people who have been born as a result of these donations and, in turn, it would allow the issuance specific confidentiality guarantees for donors against people who do not demonstrate a legitimate legal interest.

\section{References}

1. Zegers-Hochschild F, Adamson D, Dyer S, Racowsky C, De-Mouzon J, Sokol R, et al. The international glossary on infertility and fertility care, 2017. Fertil Steril. 2017;108:393-406.

2. Harper JC, Kennett D, Reisel D. The end of donor anonymity: how genetic testing is likely to drive anonymous gamete donation out of business. Hum Reprod. 2016;31:1135-1140.

3. Nahata L, Stanley N, Quinn G. Gamete donation: current practices, public opinion, and unanswered questions. Fertility Steril. 2017;107:12981299.

4. Kemelmajer-De-Carlucci AR. Origen biológico, derecho a conocer. En: Romeo-Casabona CM, director. Enciclopedia de bioderecho y bioética. España: Cátedra Interuniversitaria/Fundación BBVA/Diputación foral de Bizkaia/Universidad de Deusto/Universidad del País Vasco; 2018.

5. International Federation of Fertility Societies. IFFS surveillance 2016. Global Reprod Health. 2016;e1:1-143.

6. González-Contró M. Reflexiones sobre el derecho a la identidad de niñas, niños y adolescentes en México. Bol Mex Derecho Comp. 2011;44: 107-133.

7. Suprema Corte de Justicia de la Nación. Interés superior de los menores de edad. Necesidad de un escrutinio estricto cuando se afectan sus intereses. En: Tesis jurisprudencial P./J.7/2016 (10 $)$, pleno de la Suprema
Corte de Justicia de la Nación, 23 de septiembre de 2016 (acciones de inconstitucionalidad). Gaceta del Semanario Judicial de la Federación, décima época, libro 34, tomo 1, septiembre 2016, p.10. Disponible en: https://www.scjn.gob.mx/sites/default/files/gaceta/documentos/tomos/2016-12/libro34t1.pdf.

8. Muñoz-Genestoux R, Vittola LR. El derecho a conocer el origen genético de las personas nacidas mediante técnicas de reproducción humana asistida con donante anónimo. Rev IUS. 2016;11:207-227.

9. Brena-Sesma I. Privacidad y confidencialidad de los datos genéticos. Bol Mex Derecho Comp. 2008;número conmemorativo:109-125.

10. Gómez-Sánchez Y. El derecho a la reproducción humana. Madrid, España: Marcial Pons; 1994.

11. Théry I. El anonimato en las donaciones de engendramiento: filiación e identidad narrativa infantil en tiempos de descasamiento. Rev Antropol Soc. 2009:18:21-42.

12. Sánchez-Martínez MO. Los orígenes biológicos y los derechos de hijos e hijas: filiación y derecho a saber. Cuad Electron Filos Derecho. 2016;34:294-315.

13. Aguilar-Cavallo G. El principio del interés superior del niño y la Corte Interamericana de Derechos Humanos. Cent Estud Consti Chile. 2008;6:223-247.

14. Comité de los Derechos del Niño. Convención sobre los Derechos del Niño. Reino Unido: Naciones Unidas; 2002.

15. Alkorta-Idiakez I, Farnós-Amorós E. Anonimato del donante y derecho a conocer: un difícil equilibrio. Oñati Socio-legal Series. 2017;7:148-178.

16. Corte Interamericana de Derechos Humanos. Caso de las hermanas Serrano Cruz vs El Salvador. Sentencia de 1 de marzo de 2005. Costa Rica: Corte Interamericana de Derechos Humanos; 2005.

17. Ory SJ, Devroey P, Banker M, Brinsden P, Buster J, Fiadjoe M, et al. IFFS Surveillance 2013. EE. UU.: International Federation of Fertility Societies; 2013

18. Famá MV. El derecho a la identidad del hijo concebido mediante técnicas de reproducción humana asistida en el proyecto de código civil y comercial de la nación. Lecciones y Ensayos. 2012;90:171-195.

19. Frith L. Gamete donation and anonymity. The ethical and legal debate, Hum Reprod. 2001:16:818-824.

20. Turkmendag I. The donor-conceived child's "right to personal identity": the public debate on donor anonymity in the United Kingdom. J Law Soc. 2012;39:58-72.

21. Pennings G. The "double track" policy for donor anonymity. Hum Reprod. 1997;12:2839-2844

22. Corn E. La reproducción humana asistida en Italia. Presente y futuro después de la derogación de la prohibición de fecundación heteróloga. Rev Bioet Derecho. 2015;35:18-31.

23. Barbieri RL. Female infertility. En: Strauss J, Barbieri R. Yen and Jaffe's reproductive endocrinology. Physiology, pathophysology, and clinical management. EE. UU.: Elsevier/Saunders; 2006

24. World Health Organization [Sitio web]. Infertility definitions and terminology. Suiza: World Health Organization; 2019. Disponible en: https://www. who.int/reproductivehealth/topics/infertility/definitions/en

25. Larsen U. Research on infertility: which definition should we use? See comment in PubMed Commons belowFertil Steril. 2005;83:846-852.

26. De Melo-Martin I. How best to protect the vital interests of donor-conceived individuals: prohibiting or mandating anonymity in gamete donations? Reprod Biomed Soc Online. 2016;3:100-108.

27. Warnock M. Fabricando bebés, ¿existe un derecho a tener hijos? España: Gedia; 2004.

28. Igareda-González N. El derecho a conocer los orígenes biológicos versus el anonimato en la donación de gametos. Rev Instit Bartolomé de las Casas. 2014;31:227-249.

29. Corral-Talciani H. Intereses y derechos en colisión sobre la identidad del progenitor biológico: Los supuestos de la madre soltera y del donante de gametos. Ius et Praxis. 2010;16:57-87.

30. Vidal-Prado C. El derecho a conocer la filiación biológica (con especial atención a la filiación materna). Rev Jurid Navarra.1996;22:265-282.

31. Iniciativa que reforma y adiciona diversas disposiciones de la Ley General de Salud, a cargo de la diputada Maricela Contreras Julián, del grupo parlamentario del PRD. Gaceta Parlamentaria, año 18, número 4398-II, miércoles 4 de noviembre de 2015.

32. Iniciativa que reforma y adiciona diversas disposiciones de la Ley General de Salud, a cargo de la diputada Sylvana Beltrones Sánchez, del grupo parlamentario del PRI. Gaceta Parlamentaria, Número 4479-IV, 1 de marzo de 2016.

33. Iniciativa con proyecto de decreto que reforma el artículo 73 de la Constitución Política de los Estados Unidos Mexicanos y expide la Ley General de Técnicas de Reproducción Asistida, a cargo de la diputada Liliana Ivette Madrigal Méndez, del grupo parlamentario del PRI. (Consultada 2018 Feb 10). Disponible en: http://sil.gobernacion.gob.mx/Archivos/Documentos/2017/12/asun_3639908_20171206_1512505579.pdf.

34. Palacios-González C. Una ley que prohíbe embarazos y trasplantes. Anima Político [Sitio web]. Sección El Plumaje. México: 2016 Dec 14. Disponible en: animalpolitico.com/blogueros-una-vida-examinada-reflexiones-bioeticas/2016/12/14/una-propuesta-ley-prohibe-embarazos-trasplantes. 
35. Sistema de Acceso a la Información Pública: Infomex folios: 0063700717317 , 1225000029017. Saimex: 0057/IXEM/IP/2017.

36. Clínica IN-FIV. [Sitio web]. (Consultado 2017 Oct 17). Disponible en: http://www.clinicainfertilidadtoluca.com/index.html.

37. Inmater, [Sitio web]. (Consultado 2017 Oct 17). Disponible en: http:// inmater.com/banco-de-ovulos.

38. Embryofertyl, [Sitio web]. (Consultado 2017 Oct 17). Disponible en https://www.embriofertyl.com.mx/banco-de-semen-donacion.

39. Instituto Ingenes, [Sitio web]. (Consultado 2018 Feb 06). Disponible en: https://www.ingenes.com/donacion/programa-de-donacion-de-ovulos.

40. Viltis. [Sitio web]. (Consultado 2018 Nov 06). Disponible en: viltis.com. $\mathrm{mx} /$ donacion-de-ovulos-ovodon.

41. Centro Mexicano de Fertilidad, Dr. Alberto Kably. [Sitio web]. (Consultado 2018 Feb 21). Disponible en: http://kablyfertilidad.com/conociendo-alternativas/fivte.

42. Concibe. [Sitio web]. (Consultado 2018 Feb 06). Disponible en: http:// www.concibe.com.mx/informacion-para-donantes-de-semen.

43. Biofertility Center AIM. [Sitio web]. (Consultado 2018 Feb 21). Disponible en: http://www.biofertilitycenter.com/index.php/es/donacion-de-ovulos.

44. NASCERE. [Sitio web]. (Consultado 2018 Feb 21). Disponible en: http:// nascere.com.mx/servicios/programa-de-donacion-ovular.

45. PROCREA. [Sitio web]. (Consultado 2108 Feb 21). Disponible de: http:// www.procrea.mx/es/servicios.

46. Instituto Vida. [Sitio web]. Disponible en: http://www.institutovidamexico. com.mx/donacionovulos.html.

47. Fertility Center Cancún. [Sitio web]. (Consultado 2018 Feb 20). Disponible en: http://www.fertilitycentercancun.com.mx/donacion-esperma html.

48. Instituto Ingenes. [Sitio web]. Dudas y temores sobre la donación. Consultado 2018 Feb 06. Disponible en: https://www.ingenes.com/donacion/ programa-de-donacion-de-ovulos/.
49. Secretaría de Gobernación. Ley para la protección de los derechos de niñas, niños y adolescentes. México: Diario Oficial de la Federación 2000 May 29. Disponible en https://www.dof.gob.mx/nota_detalle. php? codigo $=2055514 \&$ fecha $=31 / 12 / 1969$.

50. Tesis aislada 1a. CXLII/2007. Rubro: Derecho a la identidad de los menores. su contenido, publicada en el Semanario Judicial de la Federación y su Gaceta, Novena Época, Tomo XXVI, julio de 2007, Materia Civil, p. 260.

51. Tesis aislada 1a. CCCXXI/2014 (10a.). Rubro: Filiación. alcances y límites del principio de verdad biológica. Gaceta del Semanario Judicial de la Federación, décima época, Tomo I, libro 10, septiembre de 2014, Materia Constitucional, Civil, p. 577.

52. Tesis Aislada 1 $1^{a}$ LXIX. Rubro: Derecho a la identidad biológica. la restricción legal al cambio filiatorio no implica la prohibición de indagar la paternidad de una persona (interpretación del art. 377 del código civil para el estado de colima). Seminario Judicial de la Federación, Décima Época, 15 de junio 2018, materia Constitucional, civil.

53. Código de Familia para el Estado de Sonora. México: Congreso del Estado de Sonora; 2007.

54. Sistema de Acceso a la Información Pública: Infomex, folio 00940617.

55. Código Civil del Estado de México. México: Congreso del Estado de México; 2002.

56. Secretaría de Salud. Norma Oficial Mexicana NOM-004-SSA3-2012, del expediente clínico. México: Diario Oficial de la Federación 2012 Jun 29. Disponible en: http://dof.gob.mx/nota_detalle_popup.php?codigo=5272787.

57. Secretaría de Gobernación. Ley Federal de Protección de Datos Personales en Posesión de los Particulares. México: Diario Oficial de la Federación 2010 Jul 05. Disponible en: https://www.dof.gob.mx/nota_detalle. php?codigo $=5150631 \&$ fecha $=05 / 07 / 2010$.

58. Tello-Moreno LF. Pruebas de ADN y presunción de la paternidad en los juicios de filiación. Derechos Hum Mex. 2006;2:225. 